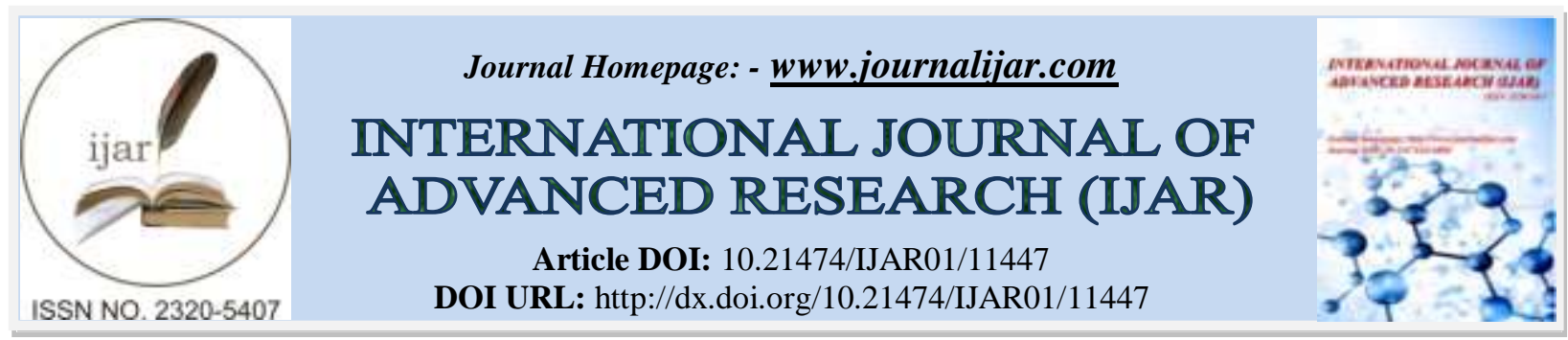

RESEARCH ARTICLE

\title{
UTILIZING GREEN INFRASTRUCTURE IN CITY OF JEDDAH'S URBAN ENVIRONMENTS FOR STORM WATER MANAGEMENT
}

Dr. Talal Hassan M. Hammadi

Umm Al Qura University/College of Engineering and Islamic Architecture, Faculty of Islamic Architecture, Saudi Arabia.

\section{Manuscript Info}

..........................

Manuscript History

Received: 31 May 2020

Final Accepted: 30 June 2020

Published: July 2020

Key words:-

Climate Change, Floods, Using Green Infrastructure, Jeddah, Landscape Urbanism, Resilience, Urban Design

\section{Abstract}

Jeddah, Saudi Arabia's largest coastal city, is positioned between two prominent natural features: the mountain range on its eastern side and the Red Sea on its west. The city faces many challenges central to which is storm water drainage. The natural drainage of the city through its pre-existing wadis, bringing down the rain water from the steep mountain ranges through the low inclining coastal plane and into the sea, has been interrupted in the last few decades by massive road infrastructural projects cutting through the city and interrupting the natural flow. The outcome of these interventions has been excessive flooding calamities, of which the ones in 2009 and2011 were the most extreme, causing severe damage to infrastructure, property and lives. Urban flooding is a serious and growing development challenge, this large and evolving challenge means that far more needs to be done by policy makers to better understand and more effectively manage existing and future risks. Green infrastructure (GI), or the nature-based solutions, encourages urban livability by decreases storm water quantity, and improves surface water quality, and provide a multitude of other environmental, economic, and social benefits. This paper is an approach to help urban planners, landscape architects, engineers, and local decision-makers in selecting and locating suitable an effectiveness of green infrastructure to manage storm water and shed light on connectivity of the existing urban water system. This paper explores the potential use of green infrastructure in City of Jeddah's urban environments as a case study, for storm water management and, to create green corridors across the city. As opposed to engineered solutions which address singular problematic, green infrastructures could supply many benefits to the city and the region. Therefore, these natural water channels (wadis) would support the development of green parks within the city, enhance social and recreational activities as well as supply ecological services ranging from carbon dioxide (co2) reduction, soil stabilization, air filtration and aquifer recharge.

Copy Right, IJAR, 2020,. All rights reserved.
Corresponding Author:- Dr. Talal Hassan M. Hammadi

Address:- Umm Al Qura University/College of Engineering and Islamic Architecture, Faculty of Islamic Architecture, Saudi Arabia. 


\section{Introduction:-}

Jeddah 's greatest challenge in the past decade has revolved around storm water drainage, the consecutive floods witnessed in 2009, 2010 and2011. (Figure 1). A great number of projects have been commissioned since to rectify the problem and to provide the city with the drainage it requires. The solutions have unfortunately been purely within the domain of engineering, and even though they have reduced the threat of flooding, have not been able to address the multi-dimensional environmental problems of the city. Jeddah suffers from underground water pollution caused by a critical absence of sewage networks, and air pollution caused by sprawl and the complete reliance on the car. Jeddah is also completely dependent on an environmentally threatening and financially costing process of water production, desalination. There is also a general lack of green areas, and the agricultural lands that once surrounded its major wadis are diminishing due to the increase in water salinity and due to climate change resulting in longer periods of drought. Even more, undeveloped surface of roads, houses and buildings are in needs for adequate planning and design of streams. Wetlands and hillsides, to be able to absorb rainfall, due to rain falls on these surfaces, the water runs off and picks up sediment and pollutants and carries them straight to our streams. This runoff can increase flooding, damage stream banks and fish habitat, and pollute streams, lakes and inlets. The practices of Green infrastructure (GI) could be a valuable technical assistance for public safety. In short, this paper can be considered as an applicable approach to safeguarding planning, construction and maintenance of green spaces and open spaces, as well as, to management and maintenance of urban outdoor urban open spaces, and water's realm, energy and transportation systems.

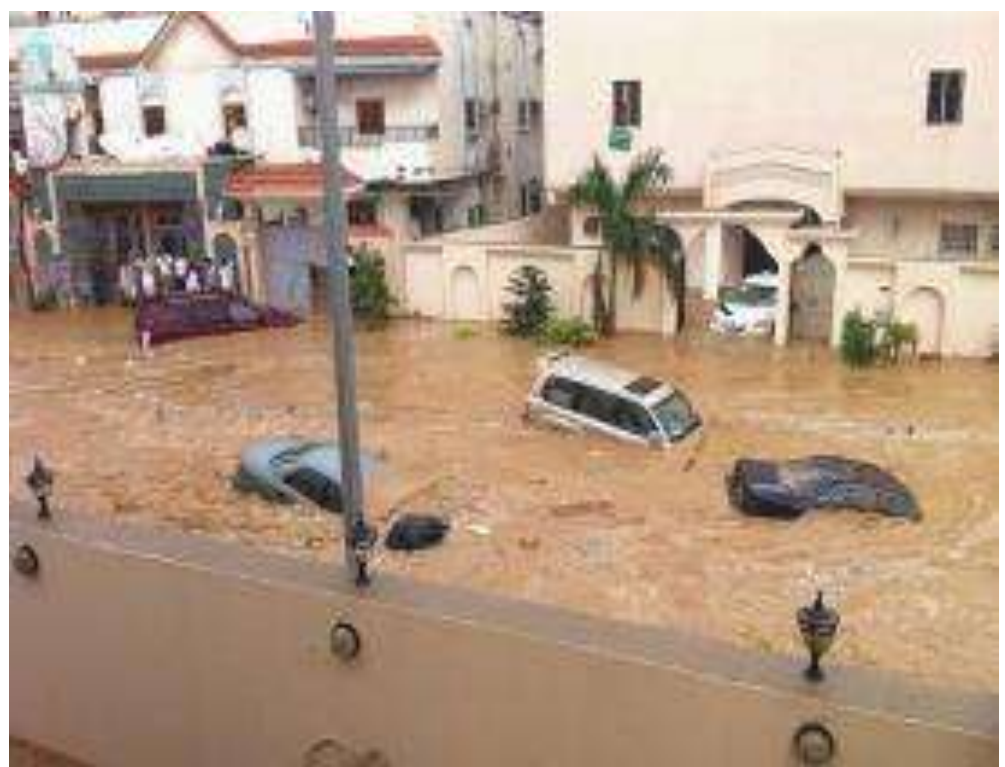

Figure 1:- A substantial number of projects have been commissioned since to rectify the problem and to provide Jeddah with the drainage it needs. The solutions have unfortunately been purely within the domain of engineering, and even though they have reduced the threat of flooding, have not been able to address the multi-dimensional environmental problems.

\section{Hypothesis:}

Jeddah's current urban environmental might be naturalizing its outdoor urban open spaces, concrete channels, via application of green infrastructure. GI naturalizing outdoor people place throughout development and restructure of various outdoor urban Open spaces and reducing their vulnerability to climate change. In other words, green infrastructure can play in mitigating the risks of flooding while bringing at the same time multiple benefits to the outdoor urban open spaces, through biodiversity conservation, heat-island mitigation, underground water replenishment, remediation of contaminated soils and urban agriculture. In fact, the need for the city to capitalize on these renewable water sources to support green infrastructure within the city, as a source of life, providing the city with the vegetation and water which it critically needs.

\section{Methodology:-}

A descriptive survey studies on Jeddah's outdoor urban Open spaces, as well as the exiting green corridors across the city, in which opposed to inadequate engineered solutions which address singular problematic, while "green 
infrastructures" could supply many benefits to the outdoor urban Open spaces of the city and the region. After studying the areas and concluding the major challenges, and the valuable opportunities of Jeddah's urban fabrics; green strategies might the best landscape architectural solution, that improved the social, cultural, environmental, and economic conditions. The type of green infrastructure introduced varied depending on the needs of the immediate and broad site conditions. Urban analysis therefore played a significant role in determining the exact onsite conditions that enabled the development of targeted strategies and urban design proposals. Urban landscape design can promote site specific solutions in comparison to urban planning which produces broad solutions that do not clearly differentiate between the various parts of the city and their respective conditions. Urban landscape design has the power of illustrating the exact physical manifestation of these concepts and enables the logical society to understand the actual impact of such interventions on their cityscape.

\section{Research Problem : Unmanaged Rapid Urbanization and the Disappearance of the Wadis:}

The humid arid conditions Jeddah, and the rapid economic development has caused pressure on city urban infrastructure and services, which explain why it is in needs for extensive landscape planning and urban design management efforts. Jeddah's problem is not the speed of urbanization per se, but the form of unmanaged urbanization that has resulted in sprawl leading to the construction of massive road networks, in the form of northsouth highways dissecting the city and interrupting its natural drainage, and the rapid and unmanaged urbanization has caused a rapid spread of informal settlements, where some of them inadequately designed and planned in environmentally sensitive areas such as low-lying lands and along major wadis. This unmanaged urbanization has thus greatly affected the natural wadis and radically altered the landscape of Jeddah triggering the violent backlash of nature experienced in the form of flash floods. (Figure 2).

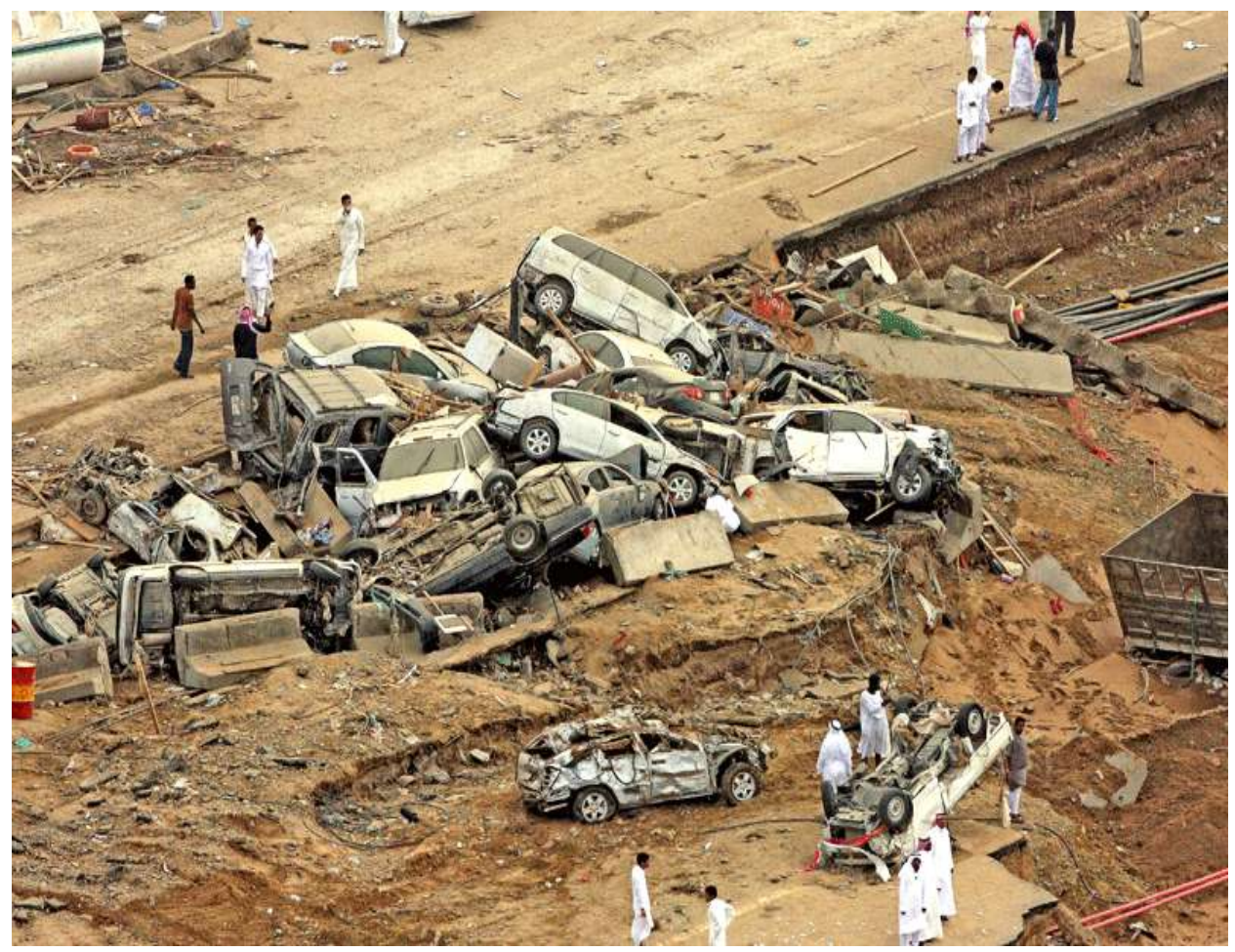

Figure 2:- The floods killed 123 people and caused widespread damage last November. Urban flooding is becoming more dangerous and costlier to manage. This is due to the sheer size of the population and to the huge geographical growth of the city.

Unfortunately, inappropriate engineering solution in the recent years has been to construct massive concrete channels to drain the rainwater safely to the sea, however the impervious nature of the channels has only succeeded in high discharge volume (and velocity) of the rain water, during precipitation periods increasing the risk of potential accidents. The proper solution encouraged in this research might be to revert the channels back to their natural state as wadis or "linear parks " to support the city's natural drainage system. Authorities of Jeddah approved several urban hydraulic projects to cope with these natural disasters, such as building dams and canals to collect 
surface waters. These urban measures aimed at the protection of inhabitants and belongings against the risks of floods as well as the interception and the drainage of water streams. Although these protection measures are important, expensive, and effective, they are no longer enough or effective to cope with the evolution of the natural disasters that the city. (Figure 3).

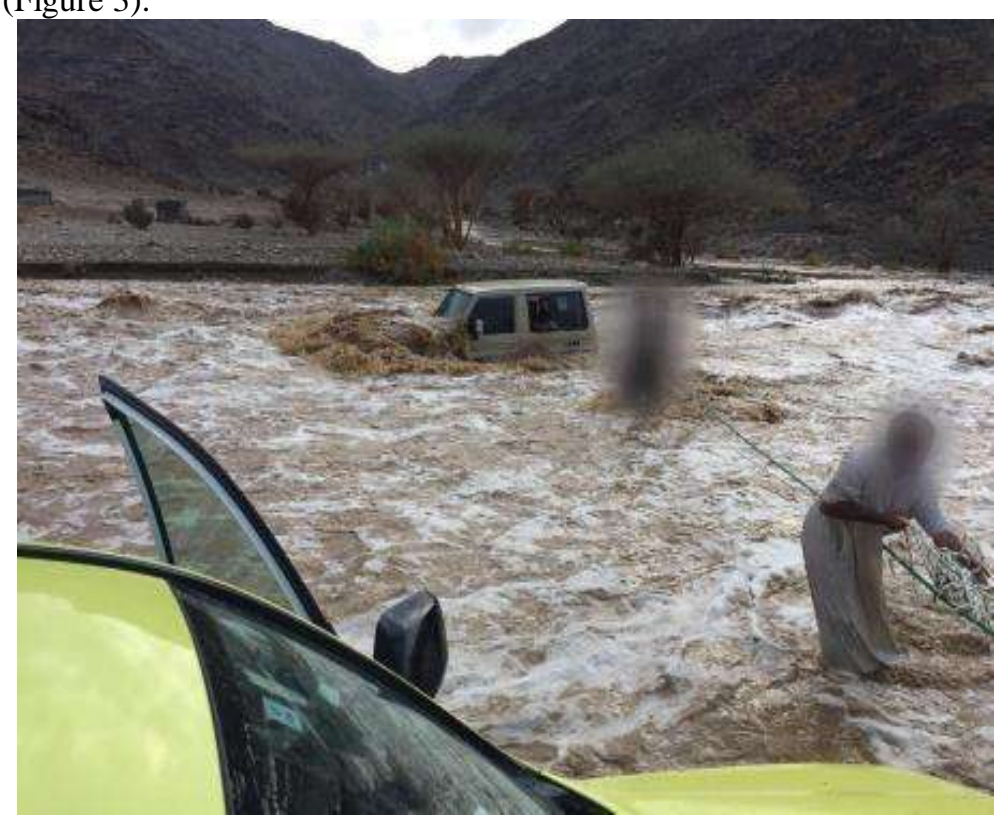

Figure 3:- Wadis - the dry beds of seasonal rivers, regularly used as roads or crossing points, or are situated alongside roads - often supply one of the biggest dangers in more remote and rural areas during times of heavy rain in Saudi Arabia. These dry beds quickly turn into raging rivers in times of rainfall, when rain moves rapidly on the dry rocks and earth and down surrounding steep slopes.

\section{Urban green infrastructure and Connectivity:}

Urban green infrastructure is a system composed of near-natural and designed spaces and elements in cities, planned and kept in such a way that the infrastructure offers high quality in terms of utility, biodiversity, and aesthetic appeal, while also, delivering a broad range of ecosystem services. Regardless of ownership or origin, all types of sites and individual elements characterized by vegetation or water can become components of the green infrastructure. Moreover, "Green Blue Urban", Founded in 1992, it was formed to conduct research into urban tree planting practices and supply solutions to aid trees in their battle to show in urban areas, as well as, the improvement of air quality in towns and cities. The growth of urban forests reduction strategies. Due to the trees as an important factor to improve the quality of life for city residents and make a positive contribution to large-scale planning and infrastructure requirements, in short, Planting trees remains one of the cheapest, most cost-effective means of drawing excess $\mathrm{CO} 2$ from the atmosphere, (Figure 1).Trees can remove and

storing harmful pollutants including:

1. Sulphur Dioxide

2. Nitrogen Oxides and Particulates

3. Carbon Monoxide

4. Cadmium

5. Nickel

6. Lead

In other meaning, " Urban Green Infrastructure (UGI) planning is a strategic planning approach that aims to develop networks of green and blue spaces in urban areas, designed and managed to deliver a wide range of ecosystem services and other benefits at all spatial scales."

Common approaches to connectivity emphasize its 'structural' dimension, i.e., the spatial structure of the outdoor urban open spaces and physical relationships between green spaces. However, such an emphasis fails to take into account the 'functional' dimensions of the landscape, i.e., the attributes and behavior of the wildlife and humans that 
interact with the overall landscape structure. Functional connectivity considers these behavioral aspects, including habitat preferences, patterns of movement and ability to adapt to changes in the environment. . (Figure4)

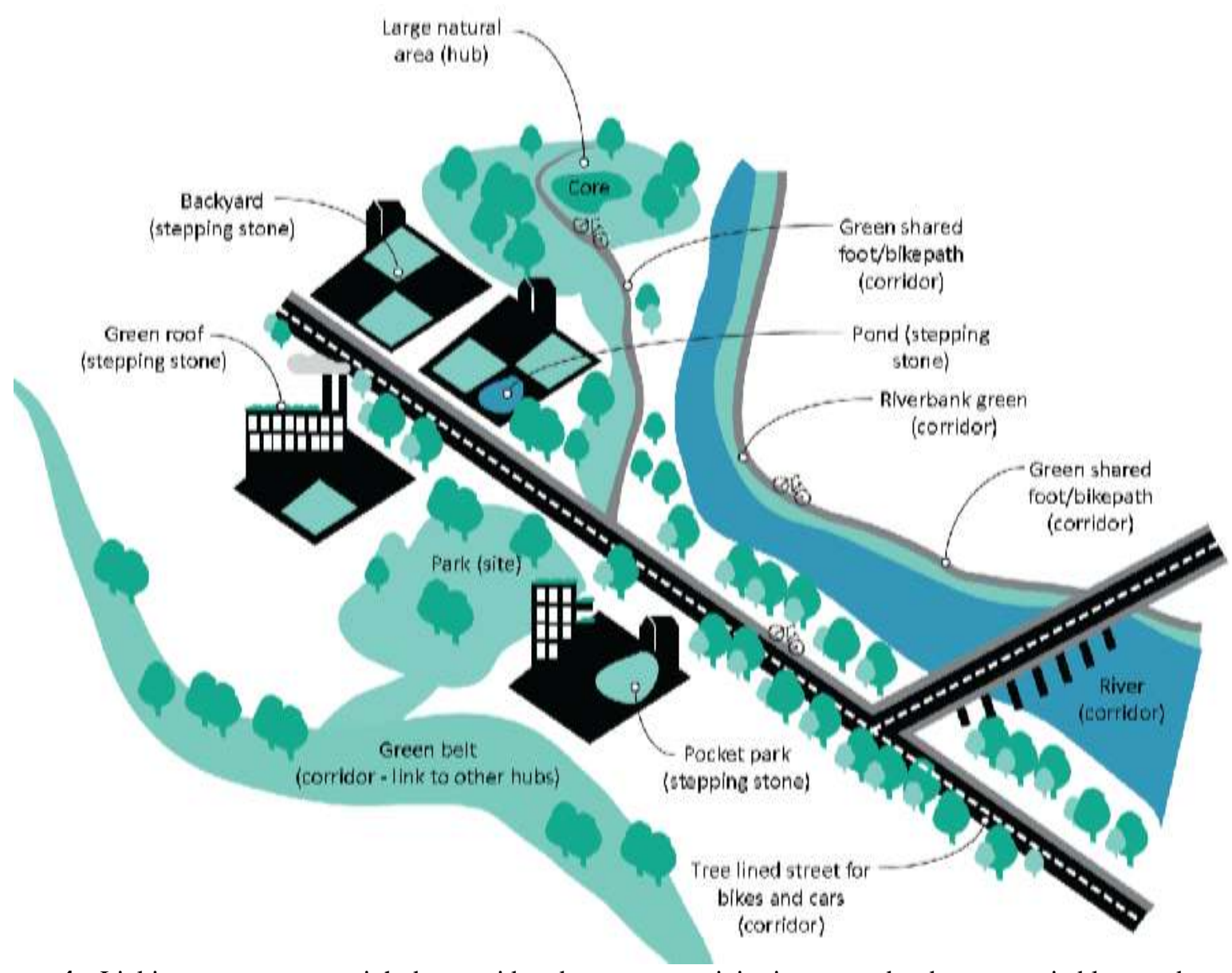

Figure 4:- Linking green spaces might be considered as a connectivity issues tend to be more suitable to reduce risk of floods impact on city outdoor urban open spaces.

Green Infrastructure and Climate Change Collaborating to Improve Community Resiliency:

Peoples across the nation already are experiencing the effects of climate change. As different parts of the country become drier, wetter or hotter, community leaders and citizens are looking to green infrastructure to improve their community's resiliency to the effects of climate change, it can help communities prepare for and manage climate change impacts as follows:

\section{Green Infrastructure to Manage Flood Risk:}

High intensity storms are expected to become more frequent and intense as global temperatures continue to rise. As a result, the risk of flooding is likely to increase dramatically. Green infrastructure can help manage both localized and riverine floods by absorbing rainfall, preventing water from overwhelming pipe networks and pooling in streets or basements. Green infrastructure, open space preservation, and floodplain management can complement gray infrastructure approaches by reducing the volume of storm water that flows into streams and rivers, protecting floodplain functions and reducing infrastructure and property damage. (Figure 5).

Therefore, this section explores the potential of planning and design Jeddah's wadis to provide the city with the green infrastructure. The east-west green corridors, wadis, and outdoor urban Open spaces will enable the city to reconnect with the sea, which is currently difficult to access, given the layout of streets and the dominancy of the North-South routes. Those net of green outdoor urban Open spaces will enable the rainwater to discharge more efficiently, slowing the speed of the discharge, and allowing for most of the water to filter down and cleanse and replenish the underground aquifers. The outdoor urban Open spaces will use the storm water to irrigate the 
landscape (larger green areas) needed to clean the city's air, stabilize the soil, and supply social, cultural and recreational amenities to the inhabitants of the city. Therefore, understanding the existing ecological systems rather than imposing a standard model of spatial development onto the landscape, to developed areas of low ecological value to protect ecological processes that supply ecosystem services.

\section{Urban Design Strategies:}

Urban design has no specific scale, it mediates between the scale of urban planning and architecture taking whichever scale needed to address the problematic. Urban design solutions cannot consider as patchwork projects that do not address the broader context. This discussion about scales of intervention will need to be researched and addressed if more lasting and sustainable solutions are to be devised. The design proposals touched upon several aspects that needed attention in the city, storm water discharge, water treatment, food production, job creation, soil decontamination, recreational and social space provision etc.
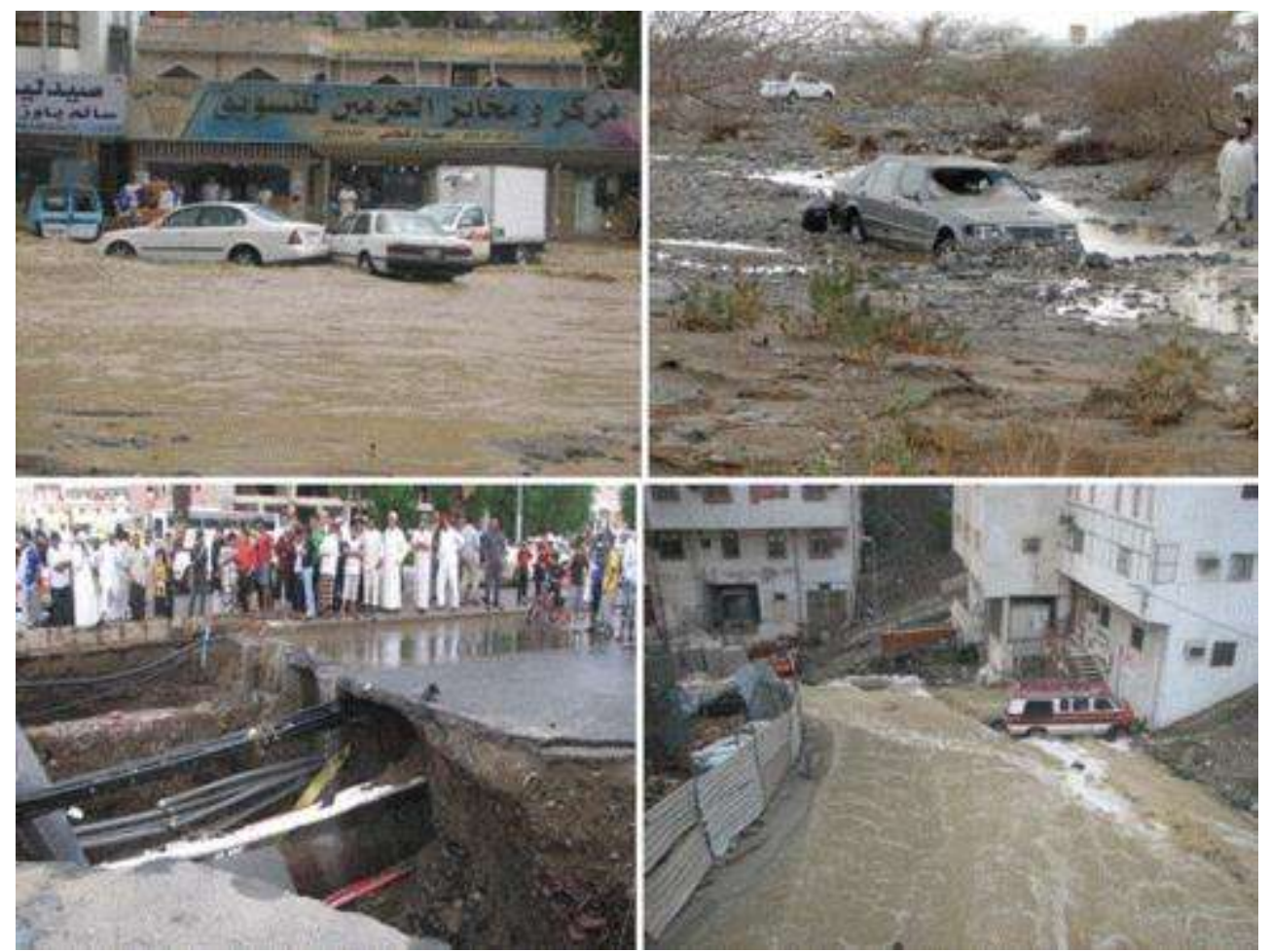

Figure 5:- In 2011 Jeddah suffered again when $11 \mathrm{~cm}$ of rain fell in 3 hours in late January and at least 10 people died in the following floods.

Each wadi managed to address its own set of challenges and to supply its own unique contribution to the city. Each wadi managed to address its own set of challenges and to supply its own unique contribution to the city. Nonetheless all the proposals had in common general green infrastructure approaches such as floodplain storage, minimal impact development, resilient planting, landscape connectivity, urban heat island mitigation, and infrastructural adjustment. These strategies when applied to the scale of the four channels/wadis crossing the city from east to west have provided the opportunity of re-writing the city in an entirely new way, allowing it to respond to climate change challenges faced in the 21 st century, while improving lifestyles for the inhabitants of the city in the present.

As with all greenway network corridors, this major connector could potentially incorporate water storage silos for certain side streets. The corridor designed to collect captured and stored water from nearby sites (including existing storm drains and contributing projects on side-streets, rooftops, gray water systems. Runoff sources such as air conditioning condensate could safely flow via sub-surface irrigation chambers to plant root zones for filtration and uptake. Water quality would enhanced via bio filtration practices that incorporate storage cells, engineered soil media, and suspended pavements; the practices would perfect the soil volumes needed for healthy street tree canopy coverage. Filtered stormwater would contribute to the subsurface storage in chambers, where it could then be recirculates back to the green infrastructure through a subsurface irrigation system. (Figure 6) 


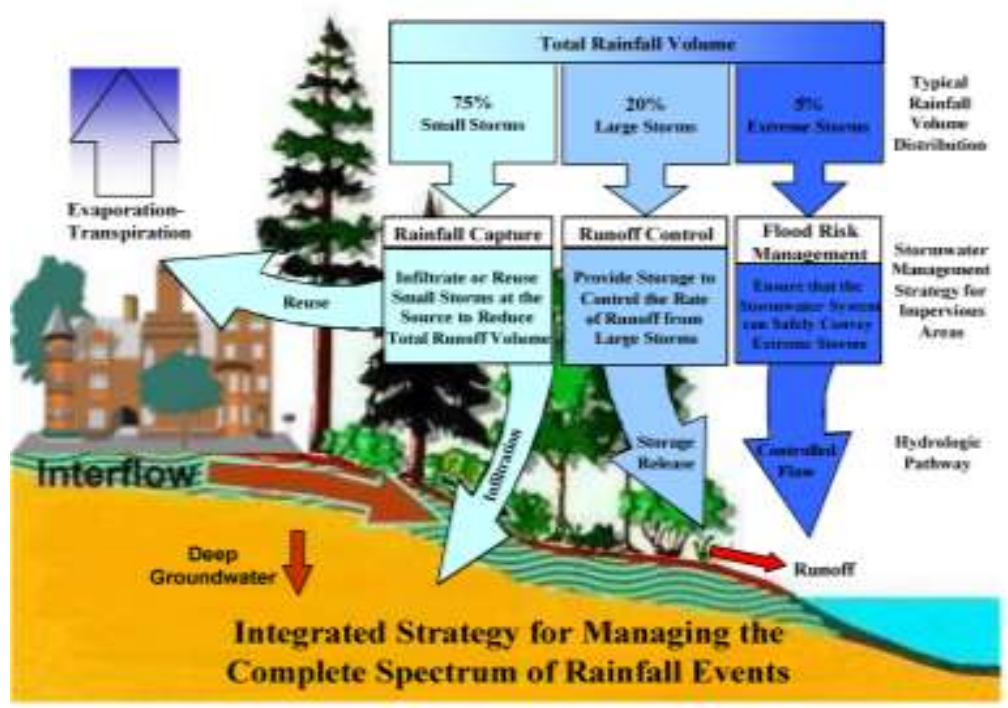

Figure 6:- The foundation of integrated stormwater solutions that mimic the most effective stormwater management system of all - a naturally vegetated watershed. This means that rainfall from frequent small events must be infiltrated into the ground or re-used within the watershed, as illustrated above.

\section{Green streets:}

A green street is a stormwater management approach that incorporates vegetation (perennials, shrubs, trees), soil, and engineered systems (e.g., permeable pavements) to slow, filter, and cleanse stormwater runoff from impervious surfaces (e.g., streets, sidewalks). Green streets are designed to capture rainwater at its source, where rain falls. Whereas, a traditional street is designed to direct stormwater runoff from impervious surfaces into storm sewer systems (gutters, drains, pipes) that discharge directly into surface waters, rivers, and streams. Green streets use green storm water infrastructure to capture stormwater and minimize the amount of pollutants that reach dry wadis, and the many tributary streams within the city. The detailed design green streets that are flexible enough to applied in a variety of urban street conditions. (Figure $6,7, \& 8$ ). Green streets reduce peak stormwater flows, free capacity in the pipes to carry more wastewater to the sewage treatment plant and reduce or stop sewer backups in basements. They can eliminate the need to install or replace expensive underground collection, conveyance and treatment systems.

\section{Anatomy of a Green Street}

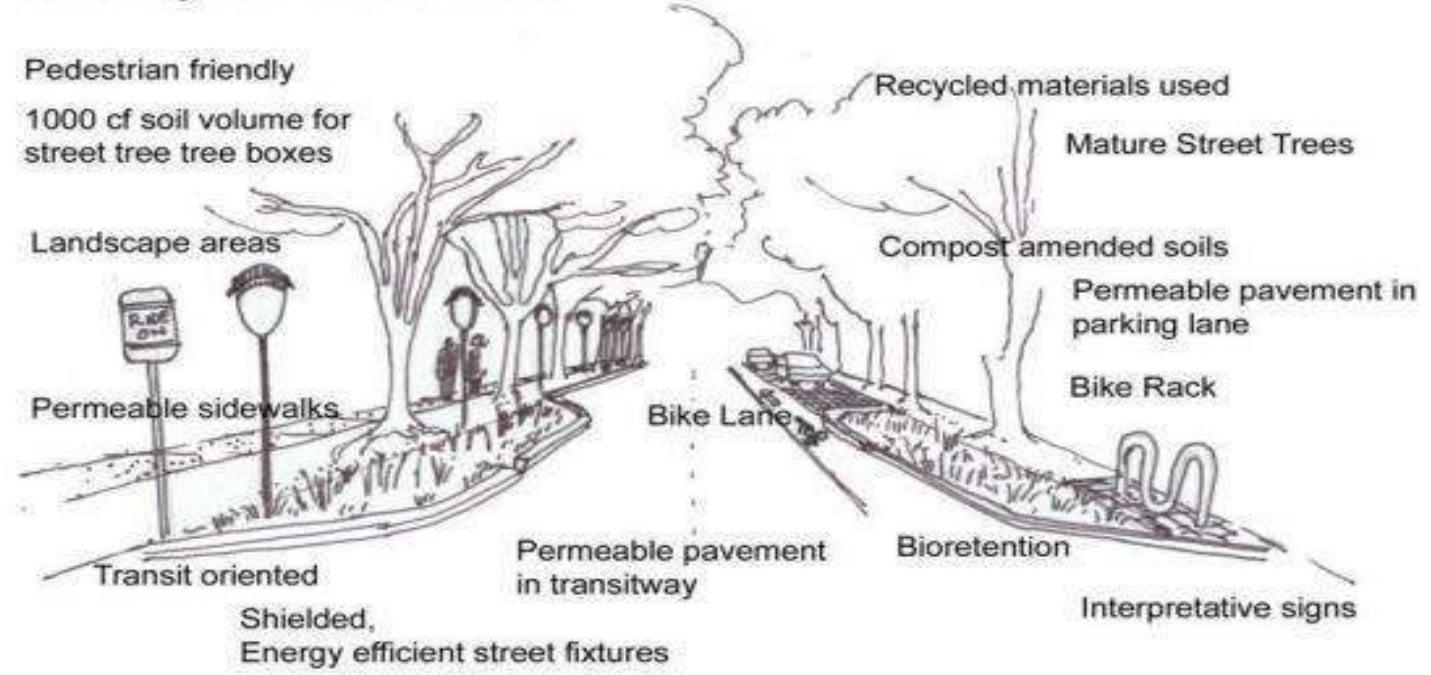

Figure 6:- The Streetscape is lined with storm water infiltration planters and includes drought-resistant plantings. The flow-through planters reduce urban runoff and minimize the need to irrigate street trees and vegetation. Photo courtesy of Hitchcock Design Group. 


\section{Urban concepts for the surrounding neighborhood area:}

Stormwater storage would be integrated as widely as possible into public areas based on landscape water demands and the volume of supply resources available, even more, Stormwater from paved areas, such as parking lots, would undergo pretreatment prior to entering infiltration galleries constructed under public rights-of-way. Open spaces would use more efficiently by planting taller trees with large canopies to intercept rainfall, absorb runoff, and supply shade to reduce the heat island effect. (Figure 9)
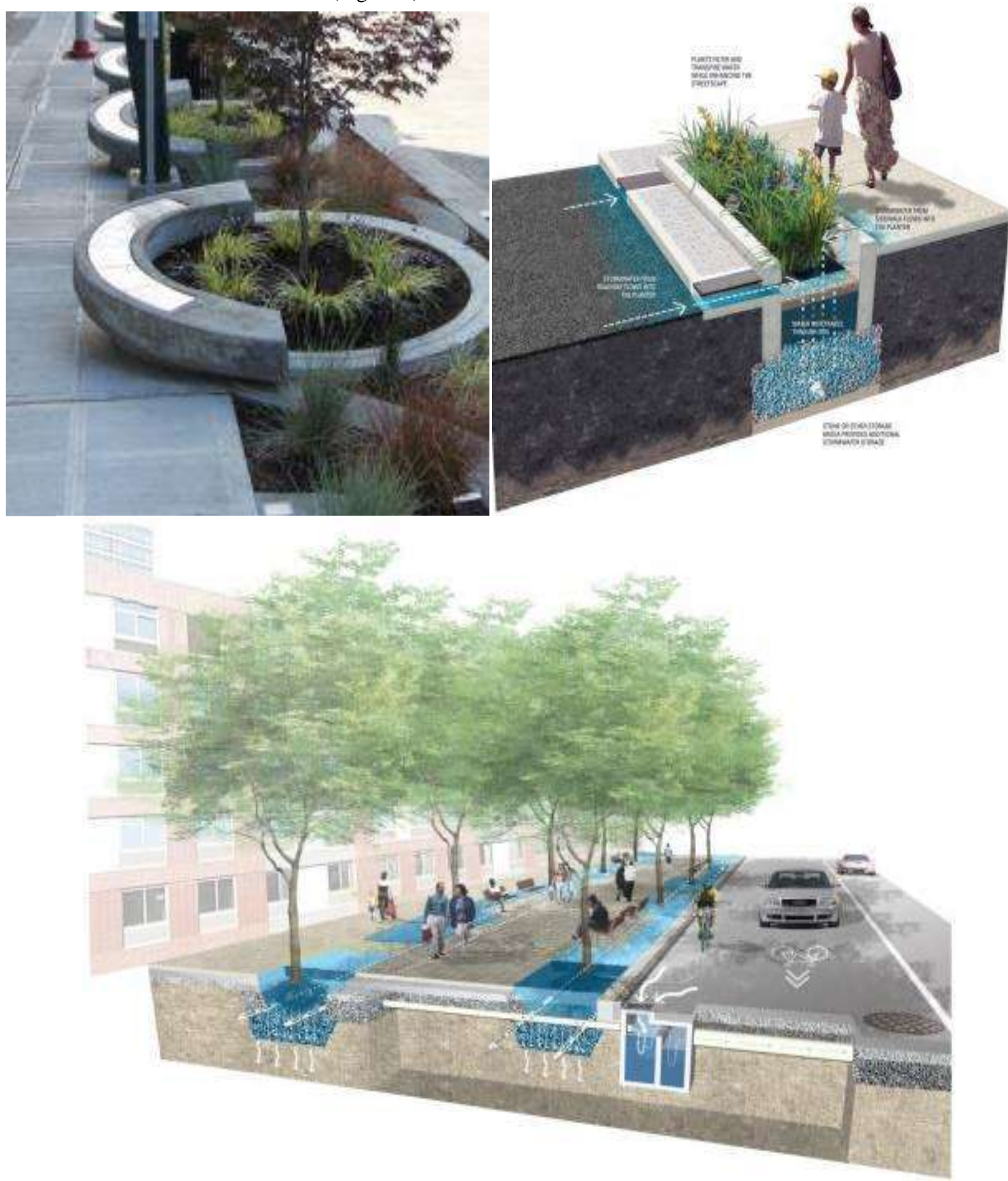

Figure 7:- City streets, are transportation networks, carrying cars, buses, pedestrians and cyclists to their destinations. But these vast stretches of pavement are also key components of cities' storm water networks. Streets cover about a third of the land in cities, and they account for half of the impervious surfaces in cities. Impervious 
surfaces don't allow water to soak through them, which means they can alter the natural flow of rainwater, therefore , managing runoff had become a more important task for to be considered during initial planning and design of outdoor urban open spaces . In fact, this is becoming an increasingly urgent problem in cities nationwide and worldwide City streets collect, channel, pollute and sometimes even speed along water as it heads to the sewers.

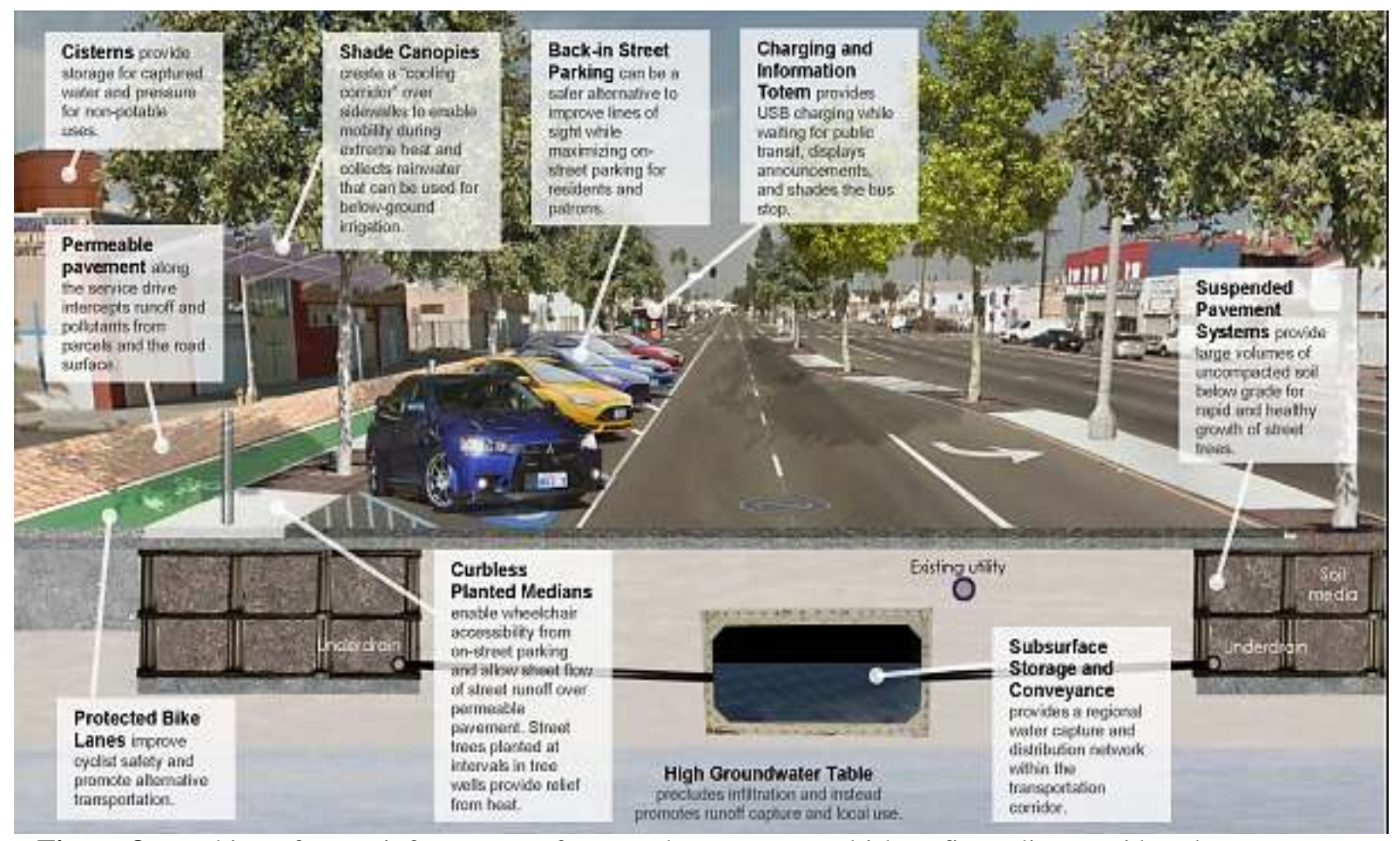

Figure 8:- Making of green infrastructure features that create a multi-benefit cooling corridor along Vermont Avenue.

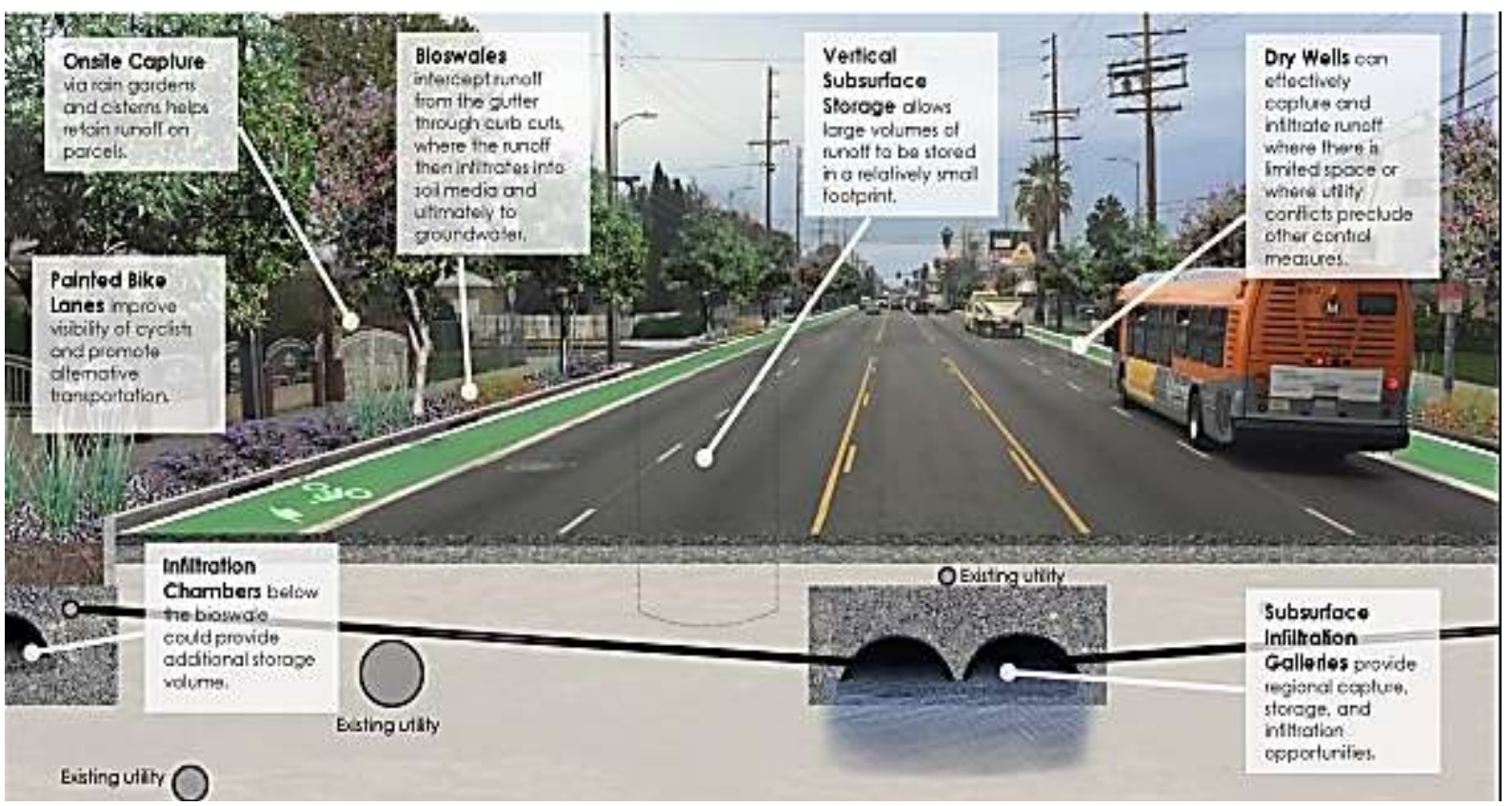

Figure 9:- Making of green infrastructure and transit streetscape improvements that would ease water capture. Green Infrastructure to combat the effects of climate change, improve community livability, and protect water resources. 


\section{Why Green Infrastructure?}

In natural areas, water is absorbed like a sponge and filtered by soils and native plants. As a result, stormwater runoff is greatly reduced. Green infrastructure, like rain gardens \& green roofs, mimic this process and alleviate polluted runoff, benefiting the environment by soaking up and storing water. Protection and management of our environment is vital to our survival. Recent human activity has resulted in pollution of land, water and air, loss of biodiversity, and degradation of our landscapes at a scale and at a rate never experienced before. This significantly limits the ability of the environment to provide these services. In addition to supplying a cost-effective and resilient approach to managing wet weather impacts, Green infrastructure provides many community benefits. Singlepurpose gray stormwater infrastructures - conventional piped drainage and water treatment systems- move urban stormwater away from the built environment. Green infrastructure reduces and treats stormwater at its source while delivering environmental, social, and economic benefits. These benefits include improving water quality and helping communities stretch their infrastructure investments further. (Figure $10 \& 11$ )

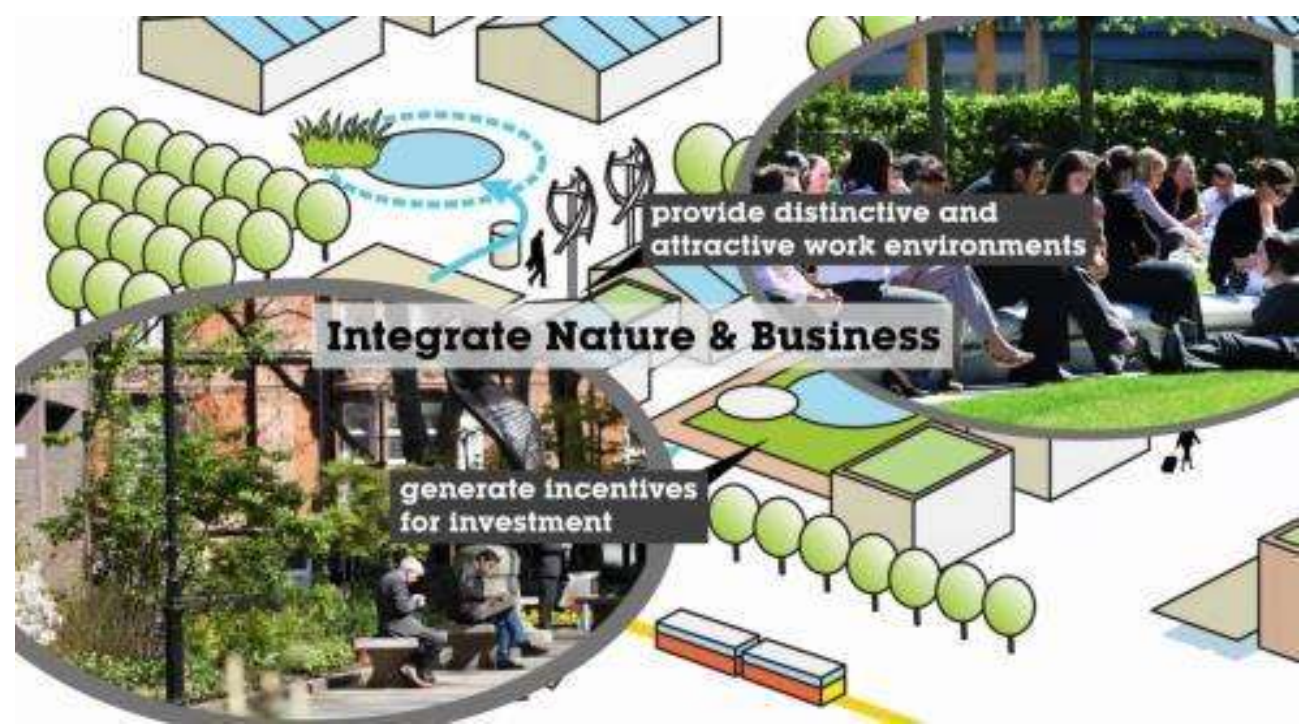

Figure 10:- Making The green infrastructure approach advocates recognizing and strengthening the ability of green infrastructure assets to deliver ecosystem services. As well as the benefits that green infrastructure provides to society.

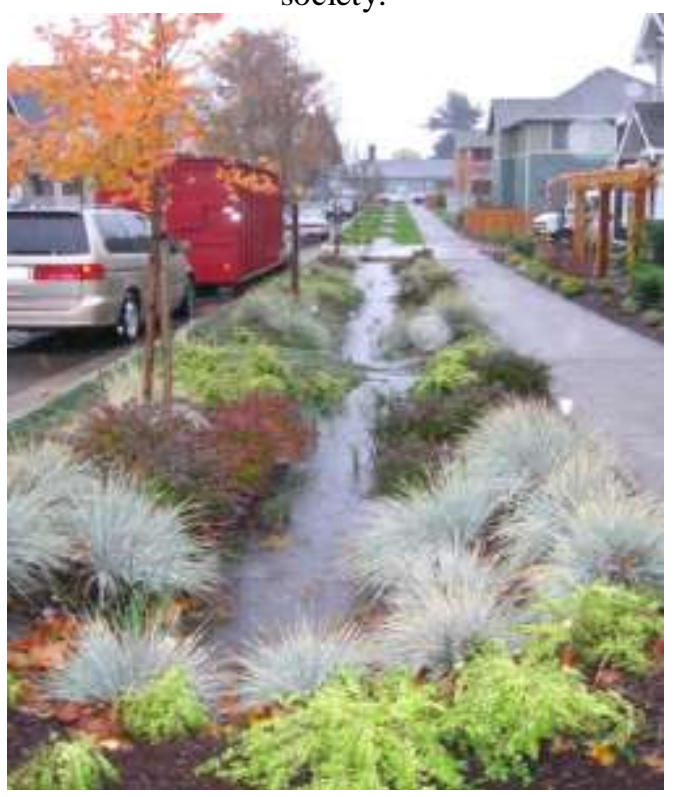

Figure 11:- Techniques such as rain gardens, like this one in the High Point neighborhood in Seattle, WA, keep stormwater runoff, which can help reduce peak flooding. 


\section{Example Green Infrastructure Practices:}

Those are some Example Green Infrastructure Practices, that might be useful for environmental designers:

\section{Bioswales:}

A bioswale looks like a dry creek bed with plants growing inside. Is an engineered with gravelly soil, so stormwater absorbed quickly and deeply. Bioswales are vegetated, mulched, or xeriscaping channels that supply stormwater treatment and retention as it moves from one place to another. Vegetated swales slow, infiltrate, and filter stormwater flows. As linear features, they are particularly well suited to place along streets and parking lots. (Figure 12 and 13).

\section{BIOSWALE}

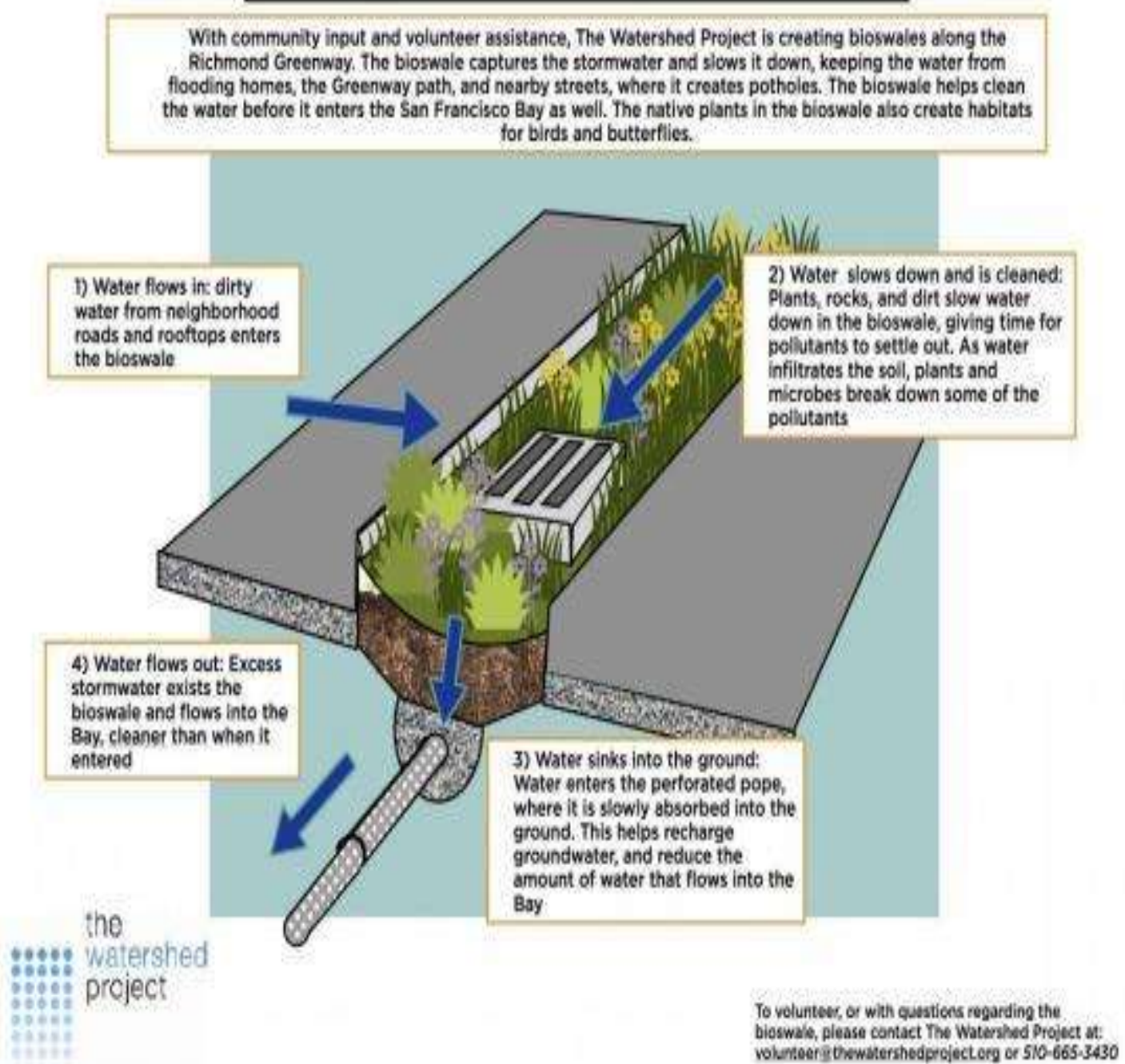

Figure 12:- A bioswale looks like a dry creek bed with plants growing inside. Is an engineered with gravelly soil, so stormwater absorbed quickly and deeply. 


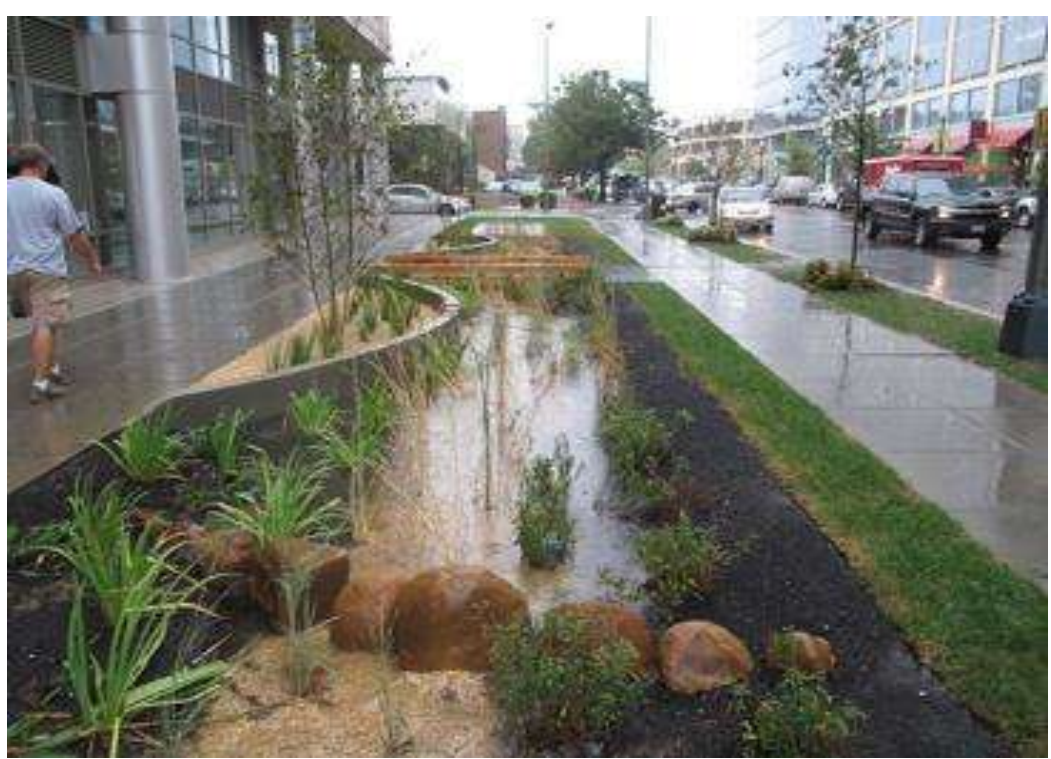

Figure 13:- A bioswale looks Bioswales are vegetated, mulched, or xeriscape channels that supply treatment and retention as they move stormwater from one place to another. Vegetated swales slow, infiltrate, and filter stormwater flows. As linear features, vegetated swales are particularly suitable along streets and parking lots.

\section{Permeable Pavements:}

Permeable pavements infiltrate, treat, and/or store rainwater where it falls. They can be made of pervious concrete, porous asphalt, or permeable interlocking pavers. This practice could be particularly cost effective where land values are high, and flooding or icing is a problem. Porous or permeable pavement surfaces are suited for parking lots, low traffic residential streets, driveways, and sidewalks. The porous or permeable surfaces allow stormwater to infiltrate into underlying soils, thereby promoting pollutant treatment and groundwater recharge. Permeable paving options include porous asphalt and concrete, block pavers, and vegetated grid systems. Permeable pavers and porous asphalt and concrete are used in higher traffic parking and roadway applications; while vegetated grid systems are more commonly used in auxiliary parking areas and roadways. (Figure 14).

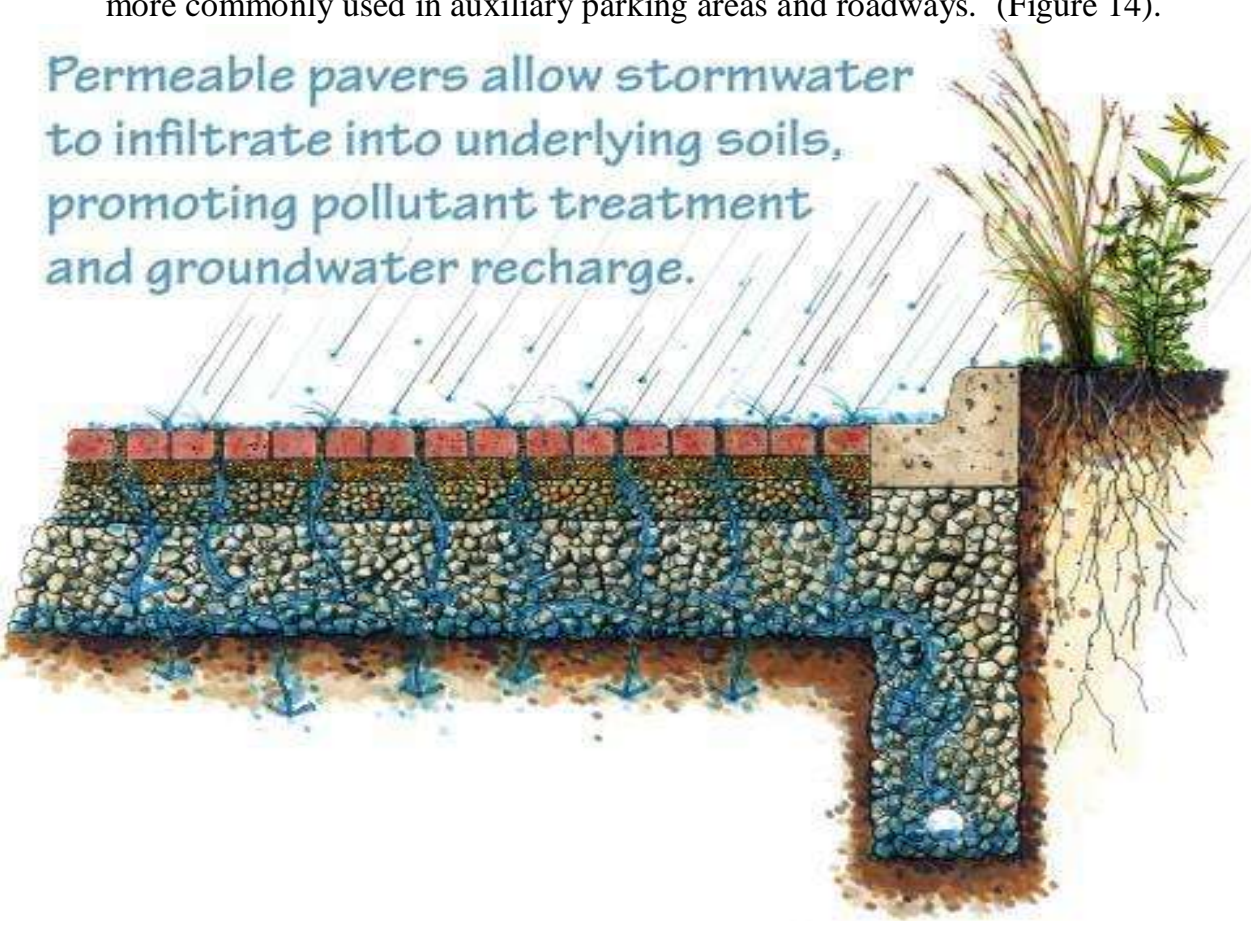

Figure 14:- Permeable Pavers Porous or permeable pavement surfaces are suited for parking lots, low traffic residential streets, driveways, and sidewalks. The porous or permeable surfaces allow stormwater to infiltrate into 
underlying soils, thereby promoting pollutant treatment and groundwater recharge. Permeable pavers are comprised of interlocking concrete bricks, separated by joints, or gaps, filled with small stones or sand, which are laid over a bed of aggregate stones. Water is able to infiltrate through the joints in the pavers and is stored in void space in the stone bed underneath the paver surface, where it is then filtered back into the soil.

\section{Green Roofs:}

Green roofs are covered with growing media and vegetation that enable rainfall infiltration and evapotranspiration of stored water. They are particularly cost-effective in dense urban areas where land values and stormwater management costs are likely to be high. (Figure 15)
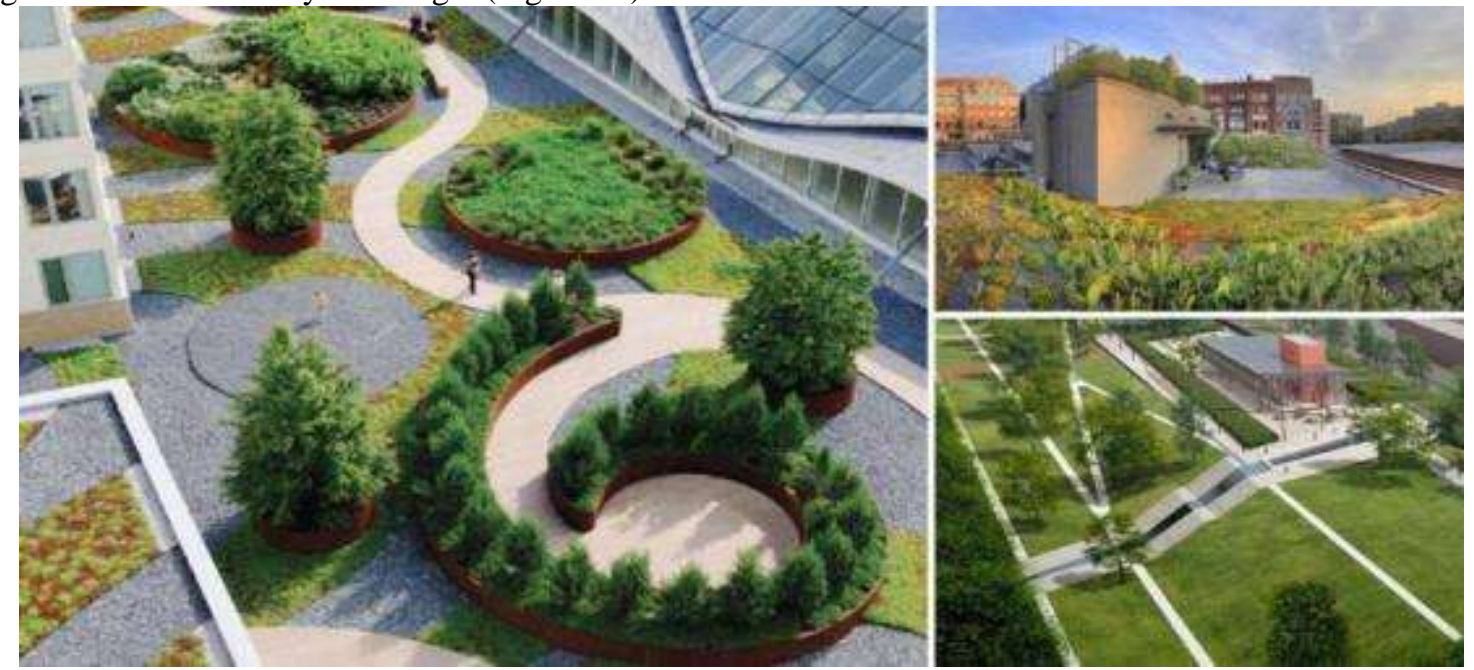

Figure 15:- As well as protecting buildings and adding character to the urban environment, green roofs can help to manage rainfall and create diverse new habitats for plants, wildlife, and people. And as we face a future with fewer wild, open spaces, we look to the use of green roofs in our cities as a way of addressing the serious issues of excess stormwater, the urban heat island effect, and soil sealing.

\section{Urban Tree Canopy:}

Urban Tree Canopy (UTC) refers to the layer of tree leaves, branches, and stems that supply tree coverage of the ground when viewed from above. Today, many Trees reduce and slow stormwater by intercepting precipitation in their leaves and branches. Many cities have set tree canopy goals to restore some of the benefits of trees that were lost when the areas were developed. Homeowners, businesses, and community groups can take part in planting and maintaining trees throughout the urban environment. (Figure 16).

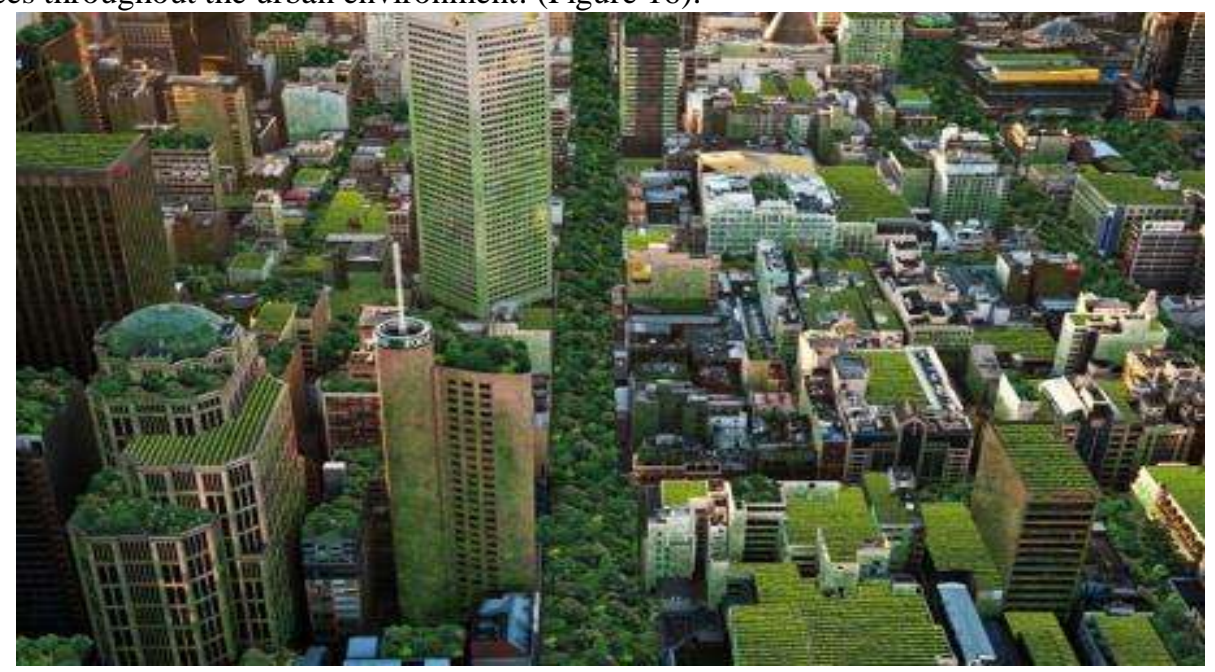

Figure 16:- The City of Melbourne's Urban Forest Strategy was awarded the 2014 Victorian Medal for Landscape Architecture from the Australian Institute of Architects Victorian chapter. Image: Anton Malishev 


\section{Downspout Disconnect:}

This simple practice reroutes rooftop drainage pipes from draining rainwater into the storm sewer to draining it into rain barrels, cisterns, or permeable areas. It can be used to store stormwater and/or allow stormwater to infiltrate into the soil. (Figure 17).

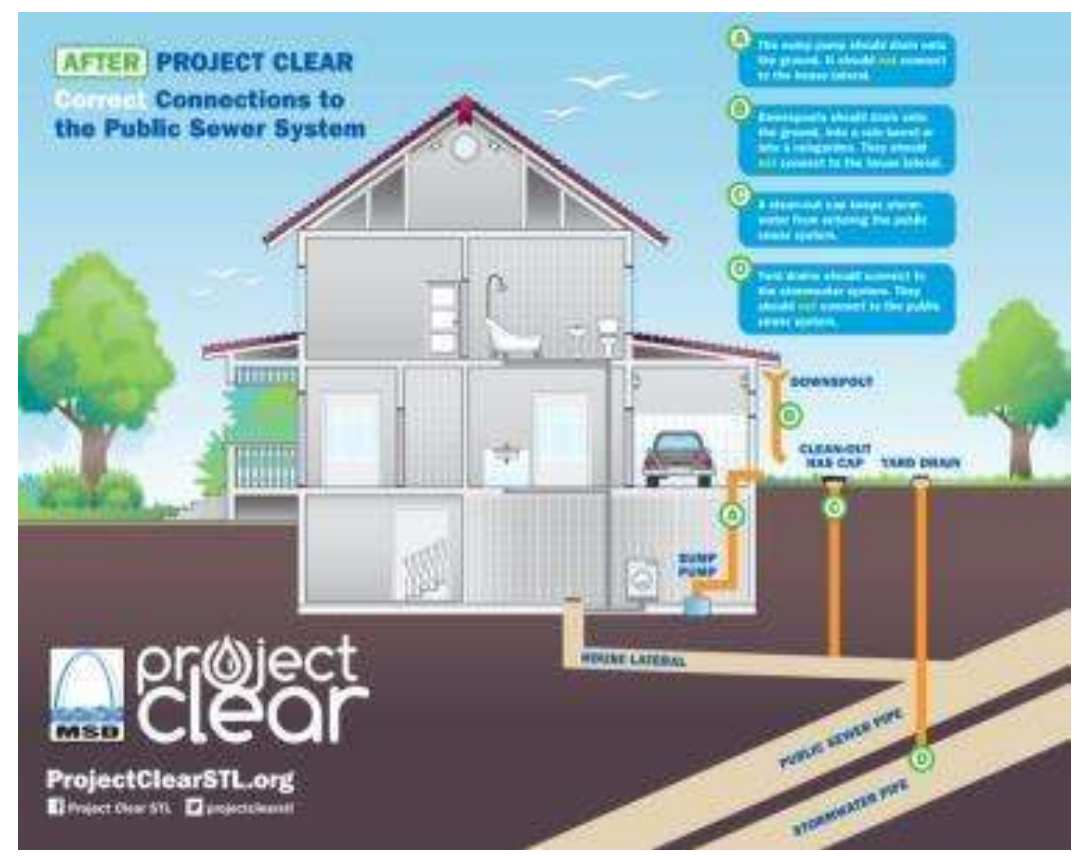

Figure 17:- This simple practice reroutes rooftop drainage pipes from draining rainwater into the storm sewer to draining it into rain barrels, cisterns, or permeable areas A primary goal of Downspout Disconnect is to get the rain out of the wastewater sewer system to reduce basement backups and overflows.

\section{Rainwater Harvesting:}

Rainwater harvesting systems collect and store rainfall for later use. When designed appropriately, they slow and reduce runoff and provide a source of water. This practice is particularly valuable in arid regions, where it could reduce demands on increasingly limited water supplies. (Figure 18).

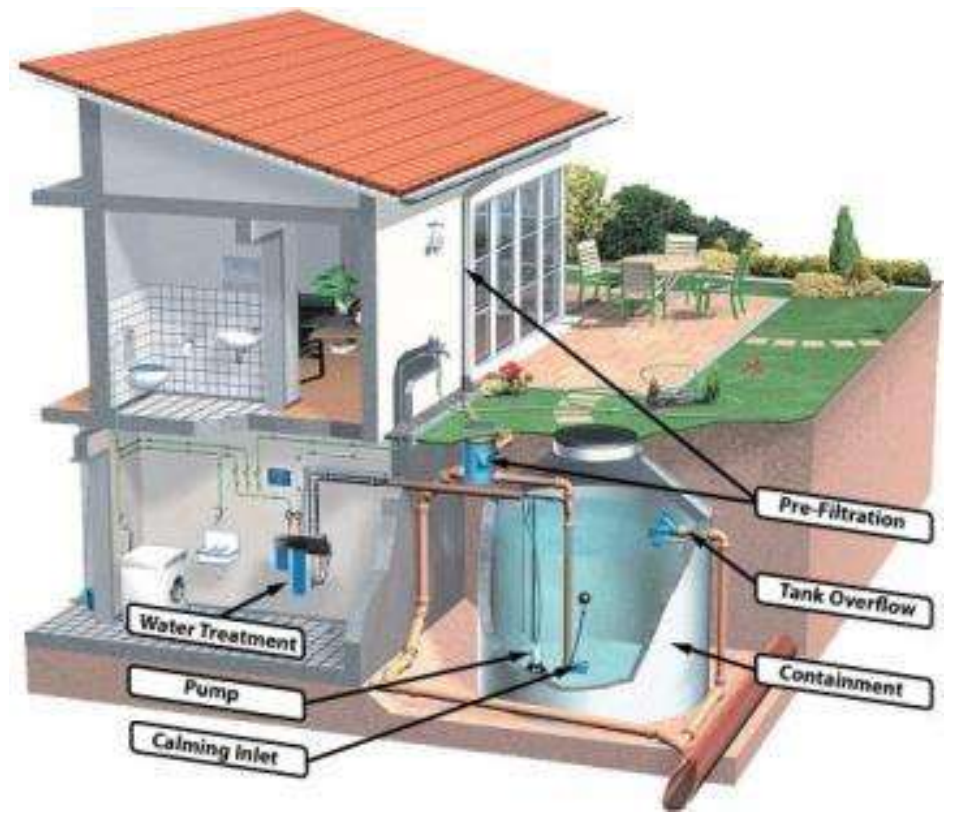




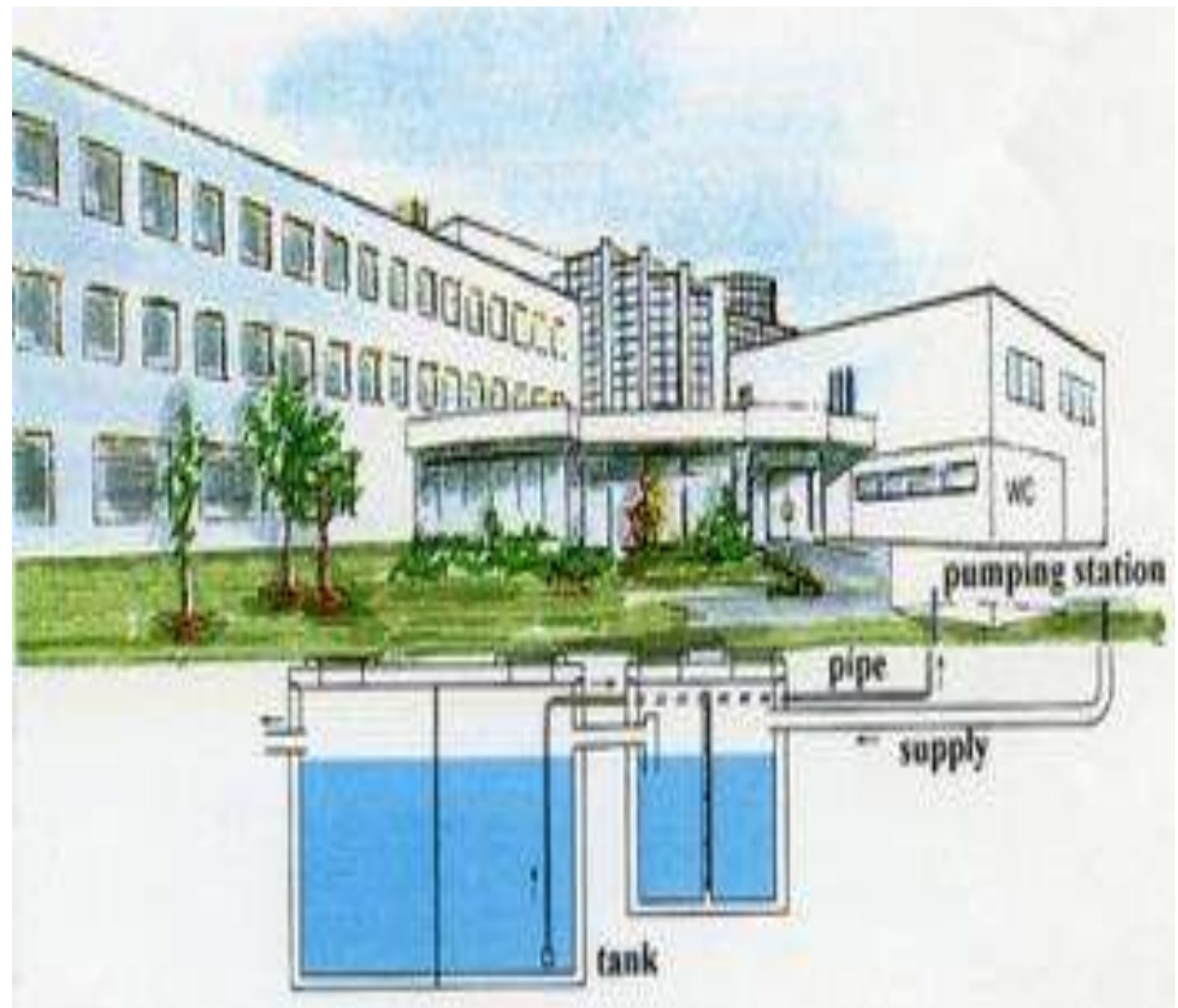

Figure 18:- Office buildings, shopping centers, apartment buildings, and other commercial properties can reap substantial benefits from rainwater harvesting. Whatever the motive - sustainability, reduced utility costs, or improved landscaping - rainwater harvesting makes profound sense for commercial property managers.

\section{Bio retention Areas \& Rain Gardens:}

Bio retention areas (also referred to as bio retention cells or rain gardens) use soil, plants and microbes to treat storm water before it is infiltrated or discharged. Bio retention areas are shallow depressions filled with sandy soil, topped with a thick layer of mulch, and planted with dense vegetation. Rain garden is a garden of native shrubs, perennials, and flowers planted in a small depression, which is generally formed on a natural slope. It is designed to temporarily hold and soak in rainwater runoff that flows from roofs, driveways, patios or lawns. Rain gardens are effective in removing up to $90 \%$ of nutrients and chemicals and up to $80 \%$ of sediments from the rainwater runoff. Compared to a conventional lawn, rain gardens allow for $30 \%$ more water to soak into the ground. A rain garden is not a water garden. Nor is it a pond or a wetland. Conversely, a rain garden is dry most of the time. It typically holds water only during and following a rainfall event. Because rain gardens will drain within 12-48 hours, they prevent the breeding of mosquitoes. Every time it rains, water runs off impermeable surfaces, such as roofs or driveways, collecting pollutants such as particles of dirt, fertilizer, chemicals, oil, garbage, and bacteria along the way. The pollutant-laden water enters storm drains untreated and flows directly to nearby streams and ponds. The US EPA estimates that pollutants carried by rainwater runoff account for $70 \%$ of all water pollution. Rain gardens collect rainwater runoff, allowing the water to be filtered by vegetation and percolate into the soil recharging groundwater aquifers. Storm water runoff flows into the bio retention area, percolates through the soil (which acts as a filter) and eventually drains into the groundwater; some of the water is also absorbed by the plants. Bio retention areas are usually designed to allow ponded water and with an overflow outlet to prevent flooding during larger storm events. Where soils have low permeability or where faster drainage is desired, designers may incorporate a perforated under drain that routes to a storm drain system (Figures 19). 


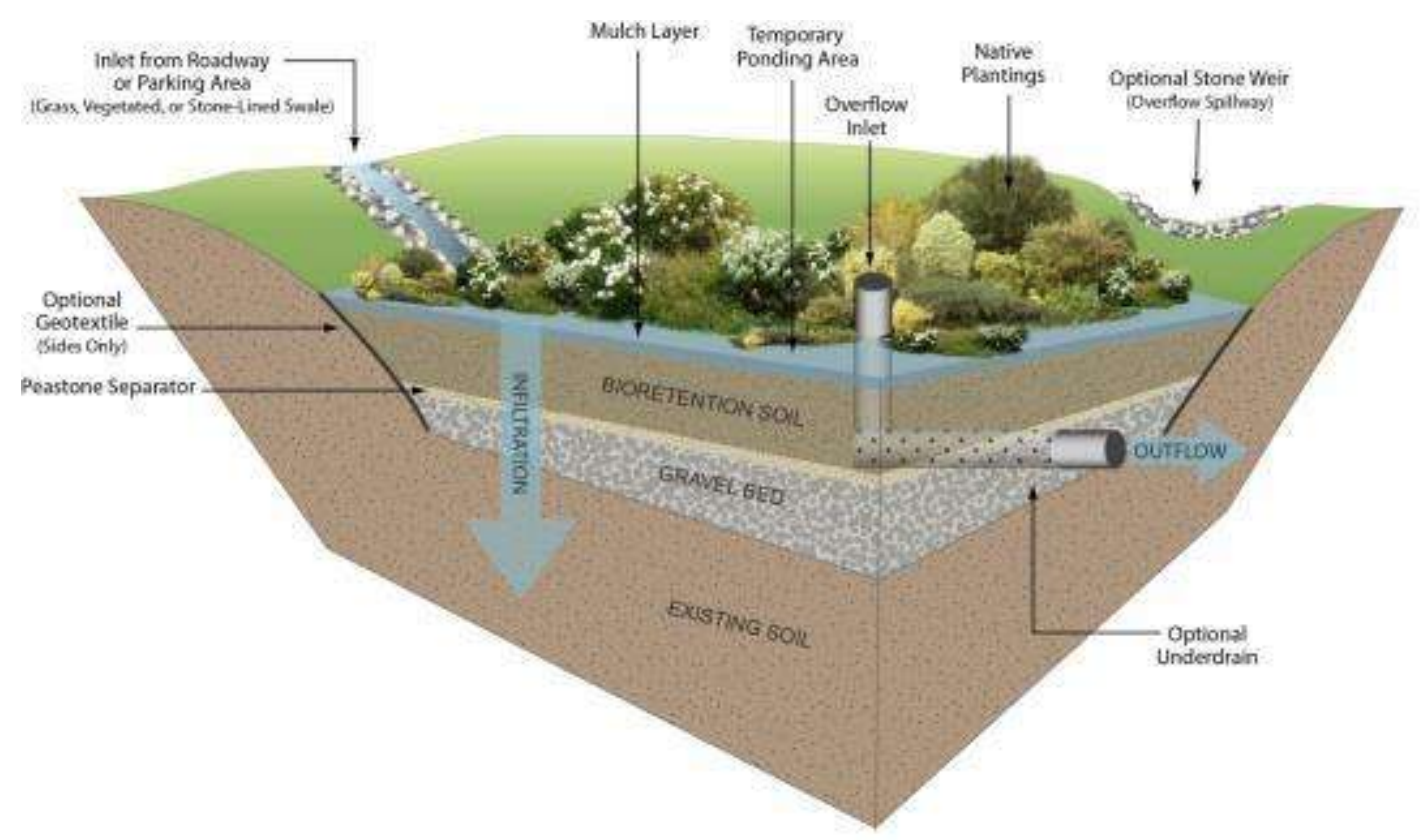

Figure 19:- Bio retention areas are suitable in a wide range of climatic and geologic situations. Common applications for bio retention areas include parking lot islands, median strips, and traffic islands. Bio retention is often a feasible "retrofit" that can be accomplished by replacing existing parking lot islands or by re-configuring a parking lot during resurfacing. On residential sites bio retention areas are commonly used for rooftop and driveway runoff.

With every rainstorm, pollutants are washed into waterways from rooftops, roadways, driveways, parking lots and sidewalks. This influx of rainwater runoff increases the severity of flooding events and adds undesirable pollutants to rivers and streams. Rain gardens offer a way to capture rainwater and allow it to permeate through the soil to reduce erosion and flooding. They slow, retain and even filter rainwater runoff using landscapes created with this special purpose in mind.

Green infrastructure practices maintain or restore stormwater's natural flow pattern by allowing the water to slowly permeate into the ground and be used by plants. These practices include rain gardens, vegetated swales, green roofs and porous pavements. Green infrastructure also includes preserving or restoring natural areas, such as forests, stream buffers and wetlands, and reducing the size of paved surfaces. Green infrastructure generally includes "better site design" or "low impact development" stormwater projects. In addition to managing stormwater, green infrastructure can recharge groundwater, provide wildlife habitat, beautify neighborhoods, cool urbanized areas, improve air quality and reduce stress on combined sewer systems.

\section{Conclusion and Recommendation:-}

Rapid urbanization, concentration of economic activity, and climate change are magnifying risks of major disasters in urban settings of Jeddah's environment. Inadequate planning and design of urban outdoor urban Open spaces, competition for space in dense urban agglomerations, and environmental degradation often result in choking of floodplains and natural catchment areas. Jeddah's Authorities implemented hard engineering or gray solutions such as dams and levees to mitigate food risk. However, with adverse impacts of floods growing, interest in a more integrated approach to urban flood risk management is growing as well. Urban Green infrastructure solutions have emerged as a key component of this integrated approach. Urban Green infrastructure solutions is an approach that focuses on using natural processes for managing wet weather impacts while delivering environmental, social, and economic benefits, such as wetlands, bio shields, buffer zones, green roofing, street side swales, porous pavements, wetlands, mangroves, and adequate planning and design of people places (Outdoor urban Open spaces ). By creating awareness of the full range of options for flood risk management, city authorities can help develop sustainable solutions with support of local communities. Even leaving their economic and safety benefits aside. Utilization of green infrastructure in city of Jeddah, might be the logical solutions for social benefits, that can be particularly useful to poor urban communities. Clean air, pleasant surroundings, and a reduced heat island effect, for example, 
can add much value to the lives of urban poor. More importantly, less pollution in urban water systems can disproportionately benefit the local society and given them better access to clean drinking water beyond municipal supply systems. It is possible to make a positive difference in efforts to mitigate risks of urban floods as well as to improve urban living conditions. For today's policy makers, experience with gray infrastructure may create a barrier to adoption of new methods. For some policy makers, cost analysis will be important, while for others hydrological models to assess water evacuation and absorption efficiency will drive decision making. Thus, more research and data collection are needed to supply systematic cost-benefit analysis as well as technical specifications of green infrastructure solutions. Urban outdoor open spaces in many cities are a welcome sight, and the aesthetic value of Green infrastructure solutions only adds to their overall appeal.

Moreover, Urban green infrastructures provide a multifunctional benefit for the urban people and the environment .The study helps to identify the opportunities and constraints in utilization of green infrastructure to develop urban outdoor urban open spaces. The study also helps to consider the interest and preference of communities on green infrastructure planning and development. Relaxation, physical exercise and social activities are the three major activities that might's be create by green infrastructure to encourage local society to enjoy landscape green outdoor areas. The results of this paper might provide a new idea and tools for city planning as better use of space, , for Engineers tool for pre design, landscape architects to tools for green solutions, Ecologist tool for watershed function, and Educators tools for social marking. It is crucial issues for all "Environmental designers" to fully consider the importance of utilization of green infrastructure for future planning and design of Jeddah's outdoor urban open spaces and places.

\section{Further Roading:-}

1. Abazza, H. (2012). Economic Considerations for Supplying Water Through Desalination in South

2. Mediterranean Countries, Report of EU Funded Project, SWIM. Retrieved from

3. http://www.swimsm.eu/files/Economic_Considerations_on_Desalination_Final.pdf

4. AlHarbi, T. H. (1989). The Development of Housing in Jeddah: Changes in Built Form from the Traditional to

5. the Modern (Unpublished PhD Thesis), Newcastle University, Newcastle.

6. Aljoufie, M., \& Tiwari, A. (2015). Climate Change Adaptations for Urban Water Infrastructure in Jeddah,

7. Kingdom of Saudi Arabia. Journal of Sustainable Development, 8(3), 52-66.

8. https://doi.org/10.5539/jsd.v8n3p52

9. Al-Sefry, A. S., \& Şen, Z. (2006). Groundwater Rise Problem and Risk Evaluation in Major Cities of Arid Lands

- Jedddah Case in Kingdom of Saudi Arabia. Water Resources Management, 20(6), 91-108.

10. https://doi.org/10.1007/s11269-006-4636-2

11. Beaumont, P. (1977). Water and Development in Saudi Arabia. The Geographical Journal, 143(1), $42-60$.

12. https://doi.org/10.2307/1796674

13. Beaumont, P. (2000). The quest for water efficiency-restructuring of water use in the Middle East. Water Air Soil

14. Pollution, 123, 551-564. https://doi.org/10.1023/A:1005225302371

15. Cerra, J. F. (2016). Inland Adaptation: Developing a Studio Model for Climate-adaptive Design as a Framework

16. for Design Practices. Landscape Journal, 35(1), 37-55. https://doi.org/10.3368/lj.35.1.37

17. Czechowski, D., Hauck, T., \& Hausladen, G. (Eds.). (2015). Revising Green Infrastructure. London: Taylor \&

18. Francis Group.

19. jsd.ccsenet.org Journal of Sustainable Development Vol. 11, No. 4; 2018

20. 239

21. Haddadin, M. J. (2003). Water issues in the Middle East challenges and opportunities. Water Policy, 4(3),

22. 205-222. https://doi.org/10.1016/S1366-7017(02)00028-4

23. Joardar, S. D. (1998). Classification of Landscape Plants for Environmental Design Uses. Journal of

24. Architectural and Planning Research, 15(2), 109-132.

25. Mortada, H. (2005). Confronting the Challenges of Urban Water Management in Arid Regions: Geographic,

26. Technological, Sociocultural, and Psychological Issues. Journal of Architectural and Planning Research,

27. 22(1), 69-81.

28. Qari, M. H. T. (2009). Geomorphology of Jeddah Governate, with Emphasis on Drainage Systems. JKAU; Earth

29. Sci, 20(1), 93-116. https://doi.org/10.4197/Ear.20-1.6 
30. Subyani, A. M. (2012). Flood Hazards Analysis of Jeddah City, Western Saudi Arabia. JAKU: Earth Sci., 23(1),

31. 35-48. https://doi.org/10.4197/Ear.23-1.3

32. Subyani, A. M., \& Hajjar, A. F. (2016). Rainfall Analysis in the Context of Climate Change for Jeddah Area,

33. Western Saudi Arabia. Arab J GeoSci., 9(122), 1-15.

34. Tarawneh, Q. Y., \& Chowdhury, S. (2018). Trends of Climate Change in Saudi Arabia: Implications on Water

35. Resources. Climate, 6(1). https://doi.org/10.3390/cli6010008

36. UN-HABITAT. (2012a). The State of Arab Cities, Challenges of Urban Transition. UN-Habitat.

37. UN-HABITAT. (2012b). Urban Patterns for a Green Economy: Working with Nature. UN-Habitat.

38. Vesey-Fitzgerald, D. F. (1957). The Vegetation of the Red Sea Coast North of Jedda, Saudi Arabia. Journal of

39. Ecology, 45(2), 547-562. https://doi.org/10.2307/2256935

40. Vincent, P. (2003). Jeddah's Environmental Problems. Geographical Review, 93(3), 394-412. https://doi.org/10.1111/j.1931-0846.2003.tb00039.x. 